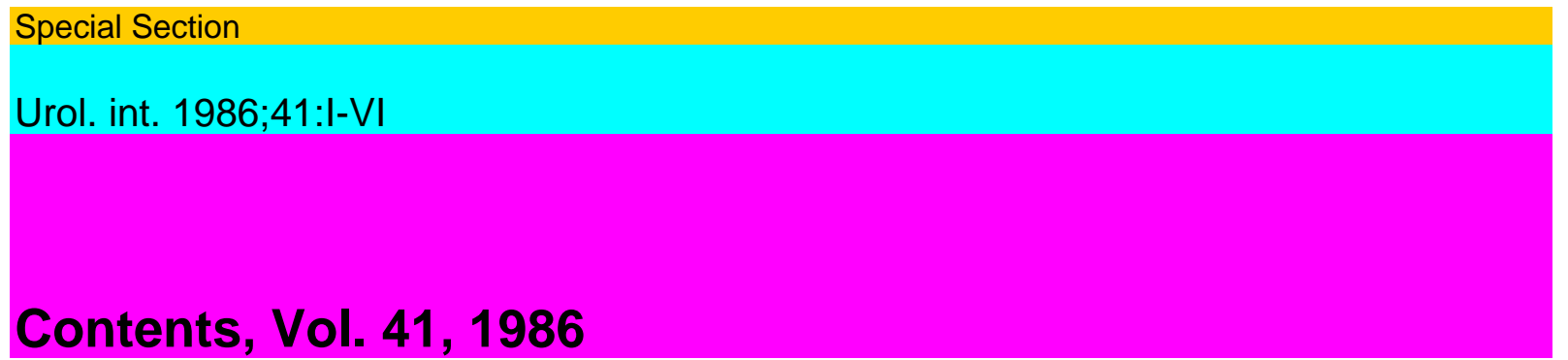

\title{
Contents Vol. 41,1986
}

No. 1

No. 2

Original Paper

Simulation of Physiological Ureteral Peristalsis

Graw, M.; Engelhardt, H 1

An Active Artificial Ureter with Autonomous Energy Supply

Graw, M; Bahl, H.U 9

Clinical Reevaluation of the Effect of Oxybutynin Chloride on

Uninhibited Neurogenic and Reflex Neurogenic Bladder

Kawabe, K.; Abe, S.; Kanda, T.; Tei, K 16

Coecocystoplasty: An Evaluation of Operative Results

Holm-Bentzen, M.; Klarskov, P.; Opsomer, R.; Hald, T. . 21 Simultaneous Measurement of

Pressure Profile and Pull-Through Force in the Urethra of 25 Female Patients

Bruijnes, E.; Klopper, P.J.; Berkhoff, W.B.C 26

Incontinence Operation for Postprostatectomy Incontinence

Hauri, D 35

Experimental Basis of Angioinfarction for the Treatment of

Renal Hypertension

Rassweiler, J.; KaufFmann, G.W.; Richter, G.; Fuchs, G.;

Miller, K 42

Fluorescence Study of Renal Carcinoma with Antibodies to

Renal Tubular Antigens, Intermediate Filaments, and

Lectins

Iizumi, T.; Yazaki, T.; Kanoh, S.; Koiso, K..; Koyama, A.;

Tojo, S 57

Bladder Inhibition by Electrical Stimulation of the Perianal Skin

Nakamura, M.; Sakurai, T.; Tsujimoto, Y.; Tada, Y. . . 62 Value of Clinical Decision on

Antibiotic Treatment of Fever

Episodes following Transurethral Resection of the Prostate

Hartzen, S.H.; Skaarup, P.; Bremmelgaard, A 64

Voiding Disturbances following Anal Surgery

Lyngdorf, P.; Frimodt-Møller, C; Jeppesen, N

Silica Stones in Humans

Haddad, F.S.; Kouyoumdjian, A 70

Case Report

Unilateral Pyonephrosis with Septic Thrombosis of the RenalVein and Vena cavaEijsten, A.;

Leisinger, H.J.; Jucker, A 77 
Notice

The Importance of the Lymphatic System

Casley-Smith, J.R $\quad 80$

Original Paper

The Excretion of Glycosaminoglycans in the Urine of Calcium-Oxalate-Stone Patients and Healthy Persons

Hesse, A.; Wuzel, H.; Vahlensieck, W 81

Urinary Excretion of Orally Administered Oxalic in Saccharin

and o-Phenylphenol-Fed NMRI Mice

Salminen, E.; Salminen, S 88

Response of the Renal Supporting Tissues to Chronic Fluoride

Exposure as Revealed by a Special Technique

Greenberg, S.R

91

Small Kidney and Hypertension: Selection of Patients for

Surgery

Ocon Pujadas, J.; Novillo, R.; Ferré, J.; del Rio, G; Castel-

let, R.; Izquierdo, F.; Algaba, F 95

Pyelonephritische Narbenbildung

Huland, H.; Busch, R.; Klosterhalfen, H 102

Urinary Infection

Puigvert, A 109

In-vitro Sensibilitätstestung von menschlichen Nierentumo-

ren gegenüber Zytostatika mit einem In-vitro-Kurzzeit-

test

Riese, W. de; Aeikens, B.; Lenis, G.; Schindler, E 112

Effect of Dibutyryl Cyclic Adenosine Monophosphate on Canine Pelviureteral Discharge

Potentials

Morita, T.; Weiss, R.M.; Suzuki, T.; Kondo, S.; Tsuchida, S. 117 Polarization Optic

Investigations on the Anatomy of the Bladder Neck and the Vesical Fundus in Women

Hanke, P.; Jonas, D.; Weber, W 121

Pelvic Floor Exercise versus Surgery for Female Urinary Stress

Incontinence

Klarskov, P.; Belving, D.; Bischoff, N.; Dorph, S.; Gersten-

berg, T.; Okholm, B.; Pedersen, P.H.; Tikjøb, G; Wormslev,

M.; Hald, T 129

Determination of Androgen Receptors in Human Benign

Prostatic Hypertrophy with Two Synthetic Radiolabeled

Ligands

Schwemmer, B.; Böttger, I.; Schiessl, J.; Reidel, G.;

Schütz, W 133

Prostaglandin E2 bei Prostatitis und Prostataadenom

Bauer, H.W.; Bach, D 139

Histological Changes in Rat Testicles after Short-Term

Ischaemia

Gilbert, P.; Wetterauer, U.; Wokalek, H

IV 
Contents

Case Reports

Postsurgical Focal Testicular Infarct

Nistal, M.; Palacios, J.; Regadera, J.; Paniagua, R 149

Acute Hemorrhagic Cystitis Caused by Adenovirus Type 11

after Renal Transplantation

Shindo, K.; Kitayama, T.; Ura, T.; Matsuya, F.; Kusaba, Y.;

Kanetake, H.; Saito, Y 152

Segmental Priapism

Borrelli, M.; Glina, S.; Wroclawski, E.R.; Celestino, J.C.;

Menezes de Goes, G 156

Therapy

Terbutaline (Bricanyl ${ }^{\circledR}$ ) in the Treatment of Female UrgeIncontinenceLindholm, P.; Lose, G 158

No. 3

Original Paper

Studies on Therapy of Metabolic Alkalosis during Experimental Uremia. Influences of ArginineHydrochloride on theIntra- and Extracellular Acid-Base Status of the RatRothe, K.F.; Flüchter,

S.H.; Schorer, R 161

Sphincteric Action of the Pelvicalyceal Junction and Pacemaker Activity in Human

KidneyMorita, T.; Wheeler, M.A.; Weiss, R.M 167

Effects of Prostaglandins on the Isolated Human Minor CalyxYano, S.; Ueda, S.; Yoshida, M.;

Ikegami, K 170

The Role of Ureteral Peristaltic Rate and Bolus Volume onIncreasing Urine FlowSaeki, H.;

Morita, T.; Weiss, R.M.; Miyagawa, $1 \quad 174$

Xanthogranulomatous Pyelonephritis. A Review with 2 CaseReportsOosterhof, G.O.N.; Delaere,

K.P.J 180

Tumorassoziiertes mononukleäres Zellinfiltrat und Rezidiv-neigung beim oberflächlichen

Urothelkarzinom der Harn-blaseFlamm, J.; Benesch, A 187

Pressure Evaluation of the Antireflux Ability of the Rat Ure-terovesical JunctionVercesi, L.A.P.;

Constantinou, C.E 192

Detrusor Instability in Children with Recurrent Urinary Tract Infection and/or Enuresis. I.

Clinical Conditions and Symptomatology

Qvist, N.; Kristensen, E.S.; Nielsen, K.K.; Ehlers, D.; Jensen, K.M.E.; Krarup, T.;

Christoffersen, J 196

Detrusor Instability in Children with Recurrent Urinary TractInfection and/or Enuresis. II.

TreatmentQvist, N.; Nielsen, K.K.; Kristensen, E.S.; Ehlers, D.; Jensen, K.M.E.; Krarup, T.; Christoffersen, J 199

Transvesical Phenolisation of the Pelvic Plexuses: A Simple Technique for the Treatment of

Refractory Detrusor Instability and Hyperreflexia

Murray, K; Mundy, A.R.; Blackford, H.N.; Stephenson, T.P 202

Blood Gas Analysis in Drug-Induced Penile Erection

Juenemann, K.-P.; Lue, T.F.; Abozeid, M.; Hellstrom, W.J.G.; Tanagho, E.A 207

Case Reports 
Hemorrhagic Infarction of the Kidney. An Uncommon Presentation of Infiltrating Urothelial Carcinoma of the Renal

Pelvis

Hitti, I.F.; Celmer, E.J.; Rapuano, J 212

Renal Angiomyolipoma Presenting as a Rupturing Abdominal

Aortic Aneurysm

Kristoffersson, A.O.; Boquist, L.; Truedson, H 216

A Case of Bilateral Metastatic Renal Tumor Originating in a

Cervical Carcinoma

Nagaoka, S.; Yamasaki, A.; Fuziwara, E.; Hayashi, M.;

Nakano, H.; Nihira, H219

Reno-Colic-Cutaneous Fistula

Maeda, O.; Nishimoto, N.; Oka, T.; Namiki, M.; Takaha,

M.; Murata, M.; Monden, T.; Okuda, H.; Sonoda, T. . . 222 Recurrent Transitional Cell

Carcinoma in an Heal Conduit

Moskovitz, B.; Levin, D.R 225

Unusual Presentation of Metastatic Carcinoma of Prostate

Chiu, K.-W.; Thorn, R.G.; Vatsia, S.K.; Ali Khan, S. . 228 Adenomatoid Tumor of the

Epididymis: Immunohistochemi-

cal Study of 8 Cases

Detassis, C; Pusiol, T.; Piscioli, F.; Luciani, L

A Case of 48, XXYY Klinefelter's Syndrome with Incurable

Skin Ulcer

Fuse, H.; Takahara, M.; Ito, H.; Shimazaki, J235

Down's Syndrome Associated with Seminoma

Sasagawa, I.; Kazama, T.; Umeda, K; Kohno, T.; Kata-

yama, T.; Miwa, A 238

No. 4

Original Paper

Electrical Stimulation of the Bladder and Gravidity

Magasi, P.; Simon, Zs 241

Initial Experience with Local Anesthesia in Extracorporeal

Shock Wave Lithotripsy

Aeikens, B.; Fritz, K.-W.; Hoehne, E 246

Laminin - a Basement Membrane Specific Glycoprotein - in

Bladder Carcinomas

Hashimoto, H.; Sakashita, S 248

A Trial of Bacillus Calmette-Guérin versus Adriamycin in

Superficial Bladder Cancer: A South-West Oncology

Group Study

Mori, K; Lamm, D.L.; Crawford, E.D

Fiberendoscopy in the Diagnosis of the Pathology of the Heal

Conduit

Martinez, E.; Viladoms, J.M.; Roca, M.; Vida, F.; Riello,

H.; Zungri, E 260

Telemetric Cystometry 
Miyagawa, I.; Nakamura, I.; Ueda, M.; Nishida, H.; Naka-

shita, E.; Goto, H 263

Contents

$\mathrm{V}$

Influence of Temperature and Stimulus Interval Variations onthe Propagation of Contractions in the Pig UreterMastrigt, R. van; Wetering, J. van de; Glerum, J.J 266

Uroflow Measurements: Their Information Yield in a Long-Term Investigation of Pre- and

Postoperative MeasurementsKarl, C; Gerlach, R.; Hannappel, J.; Lehnen, H 270

Accuracy in Core Biopsy of the Prostate. An Autopsy Study

Horndalsveen Berild, G.; Nielsen, K 276

Nuclear Magnetic Resonance in Advanced Prostate Cancer (Stage D)

Chéchile, G; Zungri, E.; Mallo, N.; Sanz, M.; Setoain, J.;Diaz, I.; Valdés, L

Does Transurethral Resection of Prostatic Carcinoma Promote Tumor Spread? Schwemmer, B.;

Ulm, K.; Rotter, M.; Braun, J.; Schütz, W. 284

Renal Parenchymal Disease: Histopathologic-SonographicCorrelationPatel, P.J 289

Renal Pelvic Peristalsis in Pigs during Standardized Flow Rate Variations Toffi, H.P.; Frøkiær,

J.; Mortensen, J.; Djurhuus, J.C. . . 292

Case Reports

Association of Pheochromocytoma with Nephrocarcinoma.Case Report and Literature

ReviewSharifi, R.; Abramowitz, J.; Lee, M 299

Removal of Renal Cell Carcinoma Extending to the Supra-diaphragmatic Vena cava with the

Aid of Cardiopulmo-nary Bypass Turini, D.; Selli, C; Barbanti, G; Beneforti, P.; Calamai, G. 303

Metastatic Malignant Melanoma of the Kidney. Case Reportand Review of the LiteratureBolkier,

M.; Ginesin, Y.; Lichtig, C; Levin, D.R 307

Cavernous Hemangioma of Scrotum and Penile Shaft

Senoh, H.; Ichikawa, Y.; Okuyama, A.; Takaha, M.;Sonoda, T 309

Treatment of Post-Traumatic Priapism by Intracavemous Injection of Alpha-StimulantMizutani, M.; Nakano, H.; Sagami, K; Nihira, H 312

Epidermoid Cyst of the Testis

Vos, P.; Beek, F.J. van der; Ingenhoes, R 315

Inferior Vena Cava Thrombus after Retroperitoneal Lymph-adenectomy for Testicular Tumor

Maeda, O.; Yokokawa, K.; Oka, T.; Namiki, M.; Fjioka, H.; Matsuda, M.; Nishiyama, M.;

Shirakura, R.; Hirose, H.;Sonoda, T 318

No. 5

Stone Diseases

Guest Editors: D. Hauri, Zurich; O. Schmucki, Luzern

Editorial $\quad 325$

Considerations on the History Lithogenesis

Puigvert, A 326

Pathophysiology of Stone Formation

Robertson, W.G 329

Critical Aspects of Urine and Stone Analysis. Appearance of

Iatrogenic Urinary Calculi

Asper, R.; Schmucki, $0 \quad 334$

Clinical Significance of Stone Analysis 
Schmucki, O.; Asper, R

343

Clinical Aspects of Stone Formation and Conservative Treatment

Ulshöfer, B 348

Extracorporeal Shock Wave Lithotripsy

Jocham, D.; Chaussy, C; Schmiedt, E 357

Ureterorenoscopy in the Treatment of Ureteral Stones (with 2

color plates)

Bichler, K.-H.; Halim, S

369

Percutaneous Litholapaxy

Korth, K; Bernius, U 375

Surgical Therapy

Hauri, D 385

Rational Prevention of Calcium Urolithiasis

Butz, M 387

Mild Metabolic Hyperoxaluria and Its Response to Pyridoxine

Gill, H.S.; Rose, G.A 393

No. 6

Original Paper

Investigation of Blood Group Antigens and Carcinoembryonic

Antigen in Urinary Bladder Carcinoma

Fujioka, Г.; Ohhori, T.; Lovrekovich, L.; Kernion, J.B. de 397 Identification of Marker

Chromosomes in Bladder Tumor

Vanni, R.; Scarpa, R.M.; Nieddu, M.; Usai, E

403

Prostaglandins in Urology

Debruyne, F.M.J.; Thomas, C.M.G 407

Anal Electrostimulation in Urinary Incontinence. Technical

Description of a New Device

Bergmann, S.; Eriksen, B.C 411

A Critical Evaluation of the Urinary Inhibiting Activity in

Idiopathic Calcium Oxalate Nephrolithiasis

Gambaro, G.; Cicerello, E.; Marzaro, G.; Marchini, F.;

Piccoli, A.; Paleari, C; Baggio, B 418

Influence of Thromboxane A2 Inhibition on the Development

of Hydronephrotic Atrophy

Huland, H.; Brenger, B.; Gonnermann, D.; Schäfer, H. . 422 Chronic Incomplete Obstruction of the Ureter: A New Experimental Model

Masui, S.; Hiratsuka, Y.; Ariyoshi, A.; Sakamoto, K. . . . 426 Acute Urinary Retention

Secondary to Benign Prostatic Hy-

perplasia. Effect of Alpha-Adrenergic Blockade

Goodwin, M.I.; Chester, J.F.; Jenkins, J.D 430

New Technique

A New Technique for the Repair of Pediatric Hydroceles

Ali Khan, S.; Vatsia, S.K.; Wasnick, R.J 432

VI

Contents 
Treatments

Use and Maintenance of Percutaneous Nephrostomy

Claes, H.; Vereecken, R.L.; Oyen, R 434

Nosocomial Urinary Tract Infections: Etiology and Prevention Brühl, P.; Widmann, T.;

Sökeland, J.; Reybrouck, G. . . 437

Treatment of Recurrent Urinary Tract Infections: Efficacy ofan Orally Administered Biological Response ModifierFrey, C; Obolensky, W.; Wyss, H 444

Case Reports

Giant Hydroureteronephrosis. Case Report and Review of theLiteratureGraff, J.; Funke, P.-J.; Hertle, L.; Senge, T 447

Fatal Outcome of Intravesical Formalin Instillation, with Changes Mimicking Renal

Tuberculosis Braam, P.F.C.M.; Delaere, K.P.J.; Debruyne, F.M.J. ... 451

Labial Adhesions in a Diabetic Woman

Kato, K.; Kondo, A.; Takita, T.; Mitsuya, H 455

N-(3',4'-Dimethoxycinnamoyl) Anthranillic Acid, an Antiallergic Compound, Induced

Eosinophilic CystitisNakada, T.; Ishikawa, S.; Sakamota, M.; Katayama, T.;Igarashi, T.;

Mizumura, Y,; Koizumi, F.; Shigematsu, H.;Fukuda, T 457

Prostatic Tumors with Penile Secondaries. Review of the Literature with a Case ReportHaddad, F.S.; Manne, R.K 465

A. Author Index 471

Subject Index 473 